\title{
Georgian Symbolism: Context and Influence
}

\author{
Tatia Oboladze*
}

Ivane Javakhishvili Tbilisi State University, Tbilisi, Georgia

Corresponding Author: Tatia Oboladze, E-mail: tatia.oboladze@gmail.com

\section{ARTICLE INFO}

Article history

Received: November 18, 2017

Accepted: January 27, 2018

Published: March 01, 2018

Volume: 7 Issue: 2

Advance access: February 2018

Conflicts of interest: None

Funding: None

\begin{abstract}
In the 1910s in the Georgian literary area the first Symbolist group TsisperiQantsebi (The Blue Horns) comes into being, with a clearly defined purpose and aesthetic position, which implied renewing the Georgian literature and including it into the Western context. Desiring to expand the thought area and to modernize Georgian literature, Georgian Symbolists rested on the philosophical and worldview principles of French Symbolism. Georgian Symbolism appears as an original invariant generated from the French Symbolist aesthetics, which is unequivocally national.
\end{abstract}

Key words: Georgian Symbolism, Georgian Modernism, The Blue Horns

In 1916, when European, namely French Symbolism in fact was a completed project, the first Symbolist literary group Tsisperi Qantsebi (The Blue Horns) ${ }^{1}$ came into being in Georgia. Young poets united to achieve a common objective, which implied restoring the artificially broken connection of Georgian literature with the Western area. Desiring to re-conceptualize the national identity and to modernize Georgian literature, Tsisperqantselebi rested on the philosophical and worldview principles of French Symbolism. Symbolism considerably determined the direction of further development of world literature and every trend taking shape within Modernism was formed to a certain extent taking into account exactly the aesthetic position of Symbolism. Thus, the fact that Tsisperqantselebi took interest in Symbolism in order to renew Georgian literature appears to be quite easy to understand. Main goal of the paper is to overcome the opinion dominating in the Soviet and Post - Soviet criticism that Georgian symbolism is artificial, anti-national phenomenon and imitation of French or Russian symbolist schools.

It should be noted that Symbolism in Georgian literature is, on the one hand, related with the name of Galaktion Tabidze, in whose work the Symbolist tendencies were revealed the most clearly, and on the other one, with the order of 13 poets Tsisperi Qantsebi. The object of our present interest is to define the role of Tsisperqantselebi in Georgian literature and to study their work, as: 1. in Georgian literature the foundation of the order of Tsisperi Qantsebi was the first precedent to create an organized literary school with well-defined objective and aesthetic position; 2. Tsisperqantselebi not only by their creative work and theoretical thought, but also by their public activities performed an enormous role in the process of Europeanization of Georgian literature and transformation of Georgia into a cultural centre, in general.

The socio-political and cultural context of France of the $19^{\text {th }} \mathrm{c}$. and Georgia of the early $20^{\text {th }} \mathrm{c}$. were totally different. In particular, the socio-political changes which followed the French Revolution of 1789 became a starting point of a new age and a model of subsequent revolutions not only in France but also in the entire Western area. As regards Georgia, from 1802 it found itself within the Russian Empire. In the 1910s (1918-1921) Georgia obtained independence for a few years, but from 1921 was forced to become one of the members of the Soviet Socialist Republic. As a result of the change of the social formation, in parallel with the revolutions and World War I, Georgia faced the necessity of re-conceptualizing the national identity. If in the $19^{\text {th }}$-c. French literature the tendencies of Romanticism and Realism (with certain variations) co-existed and it was distinguished by paradoxes, striving towards continuous formal novelties, the beginning of the $20^{\text {th }} \mathrm{c}$. is the period of stagnation of Georgian culture. Although in the work of individual authors (A.Abasheli, S.Shanshiashvili etc.) the aesthetic signs of modernism are observable, on the whole, literature was predominated by epigonism $^{2}$. Thus, despite the different cultural atmosphere, Symbolism both is France and in Georgia was preceded by a political, social, cultural or worldview crisis; precisely crisis is one of the defining factors for formation of the Symbolist trend.

From the viewpoint of the study of the history of the issue, it is interesting that at the beginning of the $20^{\text {th }} \mathrm{c}$. the appear- 
ance of the journal Tsisperi Qantsebi ${ }^{3}$ caused a sharp, mostly negative reaction. Although Tsisperqantselebi were defended by merited public figures (K.Abashidze, Ar.Jorjadze and Gr. Robakidze), the shocking behavior of the young poets, complete negation of the literary tradition, utter criticism of great authorities ${ }^{4}$ proved to be unacceptable for the majority of the Georgian society. Later on, Soviet criticism proclaimed the work of Tsisperqantselebi as an "anti-popular", negative phenomenon. After the establishing of the Soviet union, Socialist Realism was formed as the only acceptable literary discourse. "Literature, as one of the most significant ideological levers for the new authorities, soon became the proscenium of political and social "commissions": some authors obeyed this tendency with pleasure, some - under compulsion, and only a small part dared to put up resistance." (Ratiani 2013-2014: 156). Tsisperqantselebi too obeyed under compulsion the current Soviet situation, the majority of them, however, fell victim to repressions; in 1937 the founder of the group Paolo Iashvili committed suicide at the Writers' House; the main ideologists of the group Titsian Tabidze and Nikolo Mitsishvili were shot in the same year; Grigol Robakidze, recognized as the maestro by Tsisperqantselebi, emigrated to save his life, whereas others obeyed the new reality against their will. In the conditions of the Soviet totalitarian rule, although Georgian Symbolism failed to be manifested fully, its existence, as an original model, is beyond doubt.

In our view, desiring to expand the thought area and to modernize Georgian literature, Georgian Symbolists rested on philosophical and worldview principles of French Symbolism. By their manifestos, critical articles and work Tsisperqantselebi not only defined the place and role of Georgian Symbolism in the global cultural area, but also indicated clearly the Western landmarks of Georgian literature. They deliberately refused the marginal status, and after Paris announced as an art centre Tbilisi. In the process of forming their creative and worldview position Georgian Symbolists chose as the main authorities "the big four" Charles Baudelaire, Arthur Rimbaud, Stéphane Mallarmé and Paul Verlaine. By mentioning their names and texts, by devoting poems to them and translating their work, Georgian Symbolists outlined the cultural area of their work and proclaimed Georgian literature to be a part of European Modernism. "The young people who disturbed by their new song the carefree coziness of Kutaisi streets, were beginner poets... This was the new canon law of their testament. Kutaisi dukans (taverns) suddenly turned into Paris literary cafes, where alongside with hoarse sound of the organ and necessary Mravalzhamieri, the precious names were heard: Edgar Poe and Charles Baudelaire, Friedrich Nietzsche and Oscar Wilde, Paul Verlaine and Stéphane Mallarmé, and others" (Robakidze 2013: 252).

The establishment of the Georgian Symbolist group, despite the predominant view in the Soviet criticism, was not and could not have been "a phenomenon without a foundation" or blind imitation of the French of Russian Symbolist school. We consider that the foundation of the Symbolist school was a regular reaction to the social and political situation of that time (implying revolutionary turbulence, repressions of the reaction period, changes having occurred in human consciousness, scientific and technological progress, and outbreak of World War I) and taking into account Georgian epigonous literature of the 1910s. Georgian Symbolism appears as an original invariant generated from the European Symbolist aesthetics, a different model of French Symbolism, which taking into consideration national objectives, does not immediately rest on French Symbolism, but on a specific interpretation of this primary source (Balakian 1977: 9). In the Manifesto of Tsisperqantselebi we read: "There is no danger in the fact that Symbolism finds its way into our country from abroad... When the people borrow something from others, they pass it through their furnace, by means of national apperception adopt what agrees with their national peculiarity, what has a close relation with them" (Tabidze 1916:126).

It should also necessarily be noted that the ideological and aesthetic position of Tsisperqantselebi was not firm, that is why Georgian scholar Lali Avaliani notes: "The scrupulous study of the group indicates that it is not right to identify "The Blue Order"with "Georgian Symbolism". Its eclecticism (deviation towards Futurism and Dadaism), absence of consecutive ideological-aesthetic system and abundance of mutually exclusive viewpoints, sometimes opposing Symbolism, offers sufficient grounds to consider "Georgian Symbolism" only as a conventional term". (Avaliani 2012:13). Indeed, characteristic features of various Avant-garde trends, namely, Futurism and Dadaism, are clearly demonstrated in the work and manifestos of Georgian Symbolists. A clear example is the Manifesto of Tsisperqantselebi. Thus, Paolo Iashvili writes: "We glorify the beauty of destruction, reject the past... We wish Georgia to turn into an infinite, dreaming city, in which the noise of animated streets will replace the emerald of flowering valleys". (Iashvili 1916:108). Despite the eclecticism of the work of Tsisperqantselebi we think that at the initial stage of the existence of the group their work was defined by Symbolist aesthetics. We fully share the following viewpoint of Georgian literary critic Bela Tsipuria: "The Foreword with its spirit, appeals, vocabulary, in fact shows its connection immediately with the synchronic cultural context, Avant-gardism, it is noteworthy, however, that this connection was not revealed later in poetic, prose or essayist work of either Paolo Iashvili or the group" (Tsipuria 2012: 173-174).

Tsisperqantselebi's work clearly demonstrates the conceptual and stylistic resemblance with French Symbolism, relevant themes, images, motifs recur, in particular, in the work of young poets the following features derive from French literature: idea of elitism of art; aesthetics of mask; conceptualization of a poet as a magus; eroticism; urbanism; "aesthetics of ugliness"; re-mythologizing; cult of bohemianism; poetization of death (suicide); dandyism; apology of alcohol and narcotics, etc. However, unlike French Symbolists, who considered the theme of the homeland only in the ironic aspect, in the work of Tsisperqantselebi patriotism appears as the central motif. In their texts the homeland, tradition, religion are formed into a triad model. 
Thus, the Georgian Symbolism is an original invariant and definitely not a blind imitation of the French symbolism. The specificity of the Georgian Symbolist School was considerably determined by the motif of interest in the principles of French Symbolism, which was unequivocally national. The specificity of their work, namely, projection towards the national principle, is explained by the desire to determine the national identity and to modernize Georgian culture.

\section{ACKNOWLEGDMENT}

The research is supported by Shota Rustaveli National Scientific Foundation (Georgia).

\section{END NOTES}

1. Although, officially the order of Tsisperqantselebi existed till 1931, the active creative period of the group coincided with the short period of independence of Georgia - 1918-1921.

2. The main source of epigonism was the work of great Georgian Realist poet, writer, public figure Akaki Tsereteli.

3. The first issue of the almanac was published on February 28,1916 , the second - in December of the same year, under the editorship of Paolo Iashvili.Only two issues of the journal came out.
4 The society was especially indignant at the "erotic" poems of a member the group - poetess Elene Dariani. Noteworthy, Elene Dariani is the mystification of Paolo Iashvili, leader of the group.

\section{REFERENCES}

Avaliani, L. (2012). The Blue Order - Innovation, Tradition, Eclecticism. In the collection: Versification. V (Sixth Scientific Session on Versification Devoted to Tsisperqantselebi) Tbilisi: Publishing House of Institute of Literature, pp. 16-54.(in Georgian)

Balakian, A. (1977). The Symbolist Movement. A Critical Appraisal. New York: New York University Press.

Iashvili, P. (1916). Pirveltqma (Manifesto) Journal Tsisperi Qantsebi (Blue Horns), 1916, № 1.

Ratiani, I. (2013). Revolution and Creative Process. Journal Sjani, pp. 154-165 (in Georgian).

Robakidze, Gr. (2013). Georgian Modernism (translated by Manana Kvataia), Journal Kritika, №8, pp. 252-260.

Tabidze, T. (1916). With Blue Horns, Journal Tsisperi Qantsebi (Blue Horns), 1916, № 1.

Tsipuria, B. (2012). The Blue Horns and Avant-garde. In the collection: Versification. V (Sixth Scientific Session on Versification Devoted to Tsisperqantselebi) Tbilisi: Publishing House of Institute of Literature, 2012, pp.172-183.(in Georgian) 